УДК 347.124

DOI https://doi.org/10.32838/2707-0581/2020.1/16

\title{
Погребняк В.Я.
}

Національний юридичний університет імені Ярослава Мудрого

\section{ОБОРОТОЗДАТНІСТЬ СУБ’'СКТИВНИХ ЦИВІЛЬНИХ ПРАВ}

Стаття присвячена розгляду сутності оборотоздатності суб'єктивних ичивільних прав як детермінанти окремих проявів їх динаміки у сфері цивільних правовідносин.

У пошуках шляхів теоретичного вирішення порушеної проблеми автор звертається до ретельного аналізу положень чинного цивільного законодавства України. Установлюється, що в аспекті співвідношення з категоріями «обмеження цивільної оборотоздатності» й «вилучення з иивільного обороту» категорія «цивільна оборотоздатність» у контексті ст. 178 ЦК України переважно позначає здатність об'єкта вільно на правових підставах переходити між суб' 'єктами цивільного права, тобто повну цивільну оборотоздатність. При цьому зарахування об'єктів ичивільних прав до таких, щео обмежені в циивільному обороті або вилучені з нього, пов'язується переважно з їх небезпечними властивостями для учасників такого обороту, зокрема їхнього здоров'я, життя й/або майна.

Автор обтрунтовує, що об 'єктом цивільного обороту є як речі, так і суб'єктивні иивільні права на них. При цьому розгляд иивільного обороту і оборотоздатності лише через категорію переходу таких прав є неправильним. Обмеження цивільної оборотоздатності об'єкта спрямовується не лише на виключення можливості переходу права власності на нього без спеціального дозволу, а й виникнення на нього, зокрема похідних речових прав, таких як право оренди, застави тощо.

Розмежсовується широке й вузьке розуміння оборотоздатності суб'єктивних ицивільних прав. Установлюється, що в широкому розумінні оборотоздатність таких прав означає їх цивільно-правову життездатність загалом. Тобто ие здатність відповідних правових можливостей виникати як визначені положеннями чинного иивільного законодавства України суб'єктивні права й бути об'єктом иивільного обороту. У свою чергу, у вузькому розумінні оборотоздатність суб 'єктивних цивільних прав означає їх здатність вільно відчужуватися або переходити від однієї особи до іншої в порядку правонаступництва чи спадкування або іншим чином (повна чивільна оборотоздатність).

Ключові слова: иивільний оборот, цивільна оборотоздатність, динаміка прав, виникнення циивільних прав, перехід иџивільних прав.

Постановка проблеми. Категорія «цивільний оборот» нині належить до дискусійних понятійно-категоріальних проблем сучасного цивільного права. Зважаючи на іiі вагоме значення для розуміння сутності окремих проявів динаміки суб' єктивних цивільних прав, зокрема їх виникнення, переходу і припинення, іiі варто розглядати не лише в традиційному розумінні в контексті окремих властивостей речей як об'єктів цивільних прав, а і як властивість власне суб'єктивних цивільних прав, які також $є$ відповідними об'єктами відповідно до положень чинного цивільного законодавства України (ст. 177 Цивільного кодексу України (далі - ЦК України)). Крім того, у ст. 178 ЦК України прямо йдеться про оборотоздатність саме об'єктів цивільних прав, а не лише речей [1, ст. 178], що в контексті зазначеного вище зумовлює необхідність розгляду відповідних властивостей зазначених правових можливостей.
Аналіз останніх досліджень і публікацій. Проблема цивільного обороту й цивільної оборотоздатності об'єктів цивільних прав ставала предметом розгляду таких учених, як М.М. Агарков, С.С. Алексєєв, Ю.В. Вінінченко, Г.Ф. Дормідонтов, М.Л. Дювернуа, Л. Еннекцерус, І.В. Жилінкова, О.В. Зінченко, О.С. Іоффе, В.Б. Ісаков, І.Р. Калаур, А.О. Кодинець, О.О. Кот, О.В. Кохановська, О.О. Красавчиков, Є.О. Крашенінніков, В.М. Крижна, Р.А. Майданик, О.І. Міхно, С.О. Мічурін, В.В. Надьон, О.О. Отраднова, М.Д. Пленюк, Д.І. Погрібний, М.О. Рожкова, Я.М. Романюк, І.В. Спасибо-Фатєєва, Є.О. Суханов, Р.О. Халфіна, Є.О. Харитонов, Г.Г. Харченко, В.В. Цюра, А.Р. Чанишева, Г.М. Чувакова, Я.М. Шевченко, С.І. Шимон, Р.Б. Шишка, В.Л. Яроцький та ін.

Постановка завдання. Мета статті полягає у визначенні сутності оборотоздатності суб'єктивних цивільних прав як детермінанти 
окремих проявів їх динаміки у сфері цивільних правовідносин.

Виклад основного матеріалу дослідження. Пролити світло на сутність категорії «оборотоздатність» можна лише через аналіз ст. 178 ЦК України, яка є чи не єдиним положення в основному акті цивільного законодавства України, що становить нормативну основу для розуміння відповідного феномена. Цим нормативним положенням установлюється, що об'єкти цивільних прав можуть вільно відчужуватися або переходити від однієї особи до іншої в порядку правонаступництва чи спадкування або іншим чином, якщо вони не вилучені із цивільного обороту, або не обмежені в обороті, або не є невід'ємними від фізичної чи юридичної особи [1, ст. 178].

Із цього нормативного положення вбачається, що категорія «оборотоздатність» в аспекті назви зазначеної статті ЦК України і змісту аналізованого нормативного положення розкривається, зокрема, через категорії «відчуження» і «правонаступництво». Це випливає зі словосполучення «об'єкти цивільних прав можуть вільно відчужуватись або переходити від однієї особи до іншої в порядку правонаступництва чи спадкування або іншим чином», яке дає привід уважати, що оборотоздатність є властивістю тих об'єктів, які $\epsilon$ юридично відокремлюваними, тобто тими, що не мають нерозривного зв'язку з особою їх носія, а також відчужуваними, тобто такими, належність яких певній особі може бути припинена, зокрема, i у зв'язку з переходом до іншого суб'єкта, у результаті чого такий об'єкт стає «юридично чужими» для відповідної особи. Однак важливою в аналізованому положенні є наступна частина, що конкретизує аналізовану властивість: «якщуо вони не вилучені з цивільного обороту, або не обмежені в обороті, або не є невід'смними від фізичної чи юридичної особи».

Значення властивості невід'ємності в цьому сенсі розкрито нами вище. Що ж стосується невилученості із цивільного обороту й необмеженості в ньому, то вбачається, що саме ці характеристики відіграють важливу роль у розумінні сутності оборотоздатності. Зі змісту ч. 2 ст. 178 ЦК України вбачається, що об'єктами, обмежено оборотоздатними, є такі, що можуть належати лише певним учасникам обороту або перебування яких в обороті допускається за спеціальним дозволом $[1$, ст. 178]. Незважаючи на те що це положення не дає можливості встановити, що являє собою вилучення об'єкта цивільних прав із цивільного обороту, аналіз нормативно-правових актів дає при- від стверджувати, що цей феномен означає, що на відповідні об'єкти не поширюється дія цивільного законодавства в частині виникнення, переходу або припинення суб'єктивних цивільних прав на них.

Прийнято вважати, що ч. 2 ст. 178 ЦК України, у якій уживаються терміни «об'єкти, вилучені із цивільного обороту» й «об' єкти, обмежено оборотоздатні», конкретизована в положеннях Постанови Верховної Ради України «Про право власності на окремі види майна» від 17 червня 1992 року № 2471-ХII, яка містить Перелік видів майна, що не можуть перебувати у власності громадян, громадських об'єднань, міжнародних організацій і юридичних осіб інших держав на території України, а також Спеціальний порядок набуття права власності громадянами на окремі види майна. Цією Постановою до майна, яке не може перебувати у власності відповідних осіб, зараховано, зокрема, вибухові речовини й засоби вибуху, усі види ракетного палива, спеціальні технічні засоби негласного отримання інформації тощо. У свою чергу, як майно, право власності на яке може набуватися, у відповідному дозволі визначена, зокрема, вогнепальна гладкоствольна мисливська зброя, вогнепальна мисливська нарізна зброя, радіоактивні речовини тощо [2].

Отже, на підставі наведених положень можна зробити висновок, що вилучення об'єкта цивільних прав з обороту означає неможливість виникнення права власності на нього. При цьому ця обставина має визначальне значення для нейтралізації цивільно-правових схематизацій, оскільки неможливість виникнення права власності на відповідні об'єкти означає, що вони ніколи не зможуть бути предметом панування, що нівелює практично всі юридичні форми вилучення 3 відповідного блага корисних властивостей. У свою чергу, обмеження оборотоздатності об'єктів цивільних прав у контексті наведених норм чинного цивільного законодавства України означає, що право власності на відповідні об'єкти може набуватися, однак зі спеціального дозволу.

Звернення до мотивувальної основи окреслених юридичних феноменів, зокрема, у контексті зазначеної Постанови Верховної Ради України показує, що причиною обмеження цивільної оборотоздатності окремих речей і їх вилучення iз цивільного обороту $\epsilon$ їх властивості, а саме небезпека для здоров'я та життя фізичних осіб, майна фізичних або юридичних осіб, а також для інтересів суспільства. Глибокий погляд на категорію цивільної оборотоздатності в такому разі приводить нас до висновку, що оборотоздатними 
об’єктами, тобто такими, що можуть вільно відчужуватися або переходити від однієї особи до іншої в порядку правонаступництва чи спадкування або іншим чином є такі, які не становлять значну небезпеку для суб'єктів цивільного права. У свою чергу, обмеженими в обороті є об'єкти, які становлять небезпеку, однак виникнення прав на які допускається зі спеціального дозволу. Вилученими з обороту є об'єкти, які взагалі не можуть бути об'єктами права власності.

Отже, за допомогою категорій «об'єкти, вилучені із цивільного обороту» й «об'єкти, обмежено оборотоздатні» законодавець у тому числі обмежує порядок цивільно-правового регулювання суспільних відносин з певними благами або визначає сфери, відносини в яких не регулюються цивільним правом взагалі.

Однак уважаємо, що із семантичного погляду визначати категорію «оборотоздатність» лише через категорії суспільної небезпечності неправильно. Так саме не можна визначати іiї сутність через категорії «обмеження цивільної оборотоздатності» або «вилучення об'єкта цивільного обороту», для яких вона має родовий характер.

У юридичній літературі й практиці правозастосування категорія «оборотоздатність» часто вживається в більш широкому розумінні, зокрема для позначення здатності блага бути об'єктом цивільних прав загалом. Зокрема, із цього приводу Вищий спеціалізований суд України 3 розгляду цивільних і кримінальних справ в Ухвалі від 25 грудня 2013 року в судовій справі № 6-46105св13, посилаючись на ст. ст. 177, 178 і 331 ЦК України, зокрема, вказав, що успадковуватися може лише об'єкт цивільного права, а правовстановлювальні документи на спірний житловий будинок відсутні, він не набув статусу об'єкта цивільного права, що, з огляду на положення ст. 178 ЦК України, є правовою перешкодою для його вільного обігу в цивільному обороті [3]. Іншими словами, у цьому випадку суд фактично розкрив категорію «оборотоздатність» у контексті належності об'єкта особі на праві власності, у зв'язку з чим дійшов висновку, що, так як певна річ не є об'єктом права власності в силу відсутності державної реєстрації останнього за визначеним суб'єктом, ця річ не перебуває вільно в цивільному обороті.

Із цього приводу також у юридичній літературі можна зустріти позицію, в рамках якої оборотоздатність розглядається як здатність цивільних прав виступати об'єктом цивільного обороту $[4$, c. 46].
Це дає привід розмежувати два розуміння оборотоздатності - широке й вузьке. У широкому розумінні оборотоздатність є властивістю об'єкта цивільних прав загалом перебувати в цивільному обороті, тобто виступати певним об'єктом цивільних прав, зокрема права власності. У такому розумінні проявом оборотоздатності виступає в тому числі здатність переходити на цивільно-правових підставах між учасниками цивільних правовідносин. Тобто в цьому сенсі оборотоздатність практично ототожнюється з об'єктоздатністю. У свою чергу, у вузькому розумінні оборотоздатність являє собою здатність певного об'єкта вільно відчужуватися або переходити від однієї особи до іншої в порядку правонаступництва чи спадкування або іншим чином. Тобто в такому розумінні оборотоздатність розглядається в розумінні «повної оборотоздатності», що в термінологічному ключі перебуває в одному ряді з «обмеженою оборотоздатністю» й «вилученням із цивільного обороту».

Проблема оборотоздатності в широкому розумінні в контексті предмета розгляду зіштовхується 3 двома концептуальними моментами, якими є власне об'єкт, що наділений здатністю до обороту, тобто чи є ними блага, суб'єктивні цивільні права на них або ж і те й інше, а також форми цивільного обороту, тобто які саме дій або події визначають його зміст.

У цьому сенсі варто відмітити, що в сучасній юридичній літературі простежується плюралізм підходів до визначення сутності цивільного обороту. Зокрема, він розглядається і як сукупність юридичних фактів, правочинів, і як сукупність відносин, і як сукупність норм, і як сукупність випадків зміни правоволодільців. Поряд із цим одним із найбільш популярних і конструктивних підходів виявляється погляд на цивільний оборот як процес переходу (руху), зокрема, прав та обов'язків або матеріальних об'єктів [5, с. 207].

У цьому сенсі абз. 2 ч. 2 ст. 178 ЦК України дає привід уважати, що об'єктом цивільного обороту є як блага, так і суб'єктивні цивільні права на них, якщо останні є віддільними від особи, особливо зважаючи на те що в окремих випадках суб'єктивне цивільне право й виступає в ролі такого блага, прикладом чому є правочини, учинювані стосовно відповідних правових можливостей, зокрема відступлення права вимоги.

Звертаючись до речових правовідносин, які переважно використовуються як платформа для розкриття сутності цивільного обороту, необхідно порушити проблему телеологічної спрямованості 
обмеження останнього. Умовно розмежовуючи майнове благо, зокрема річ, а також суб'єктивні цивільні права на неї, які мають речовий характер, ми можемо побачити дійсний сенс обмеження обороту таких прав і майнових благ. Зокрема, якщо об' єктом обмеження цивільного обороту $\epsilon$ майнове благо, то в такому разі для його передачі особи, між якими вона має місце, повинні відповідати визначеним вимогам або ж мати спеціальні дозволи. Однак якщо такі блага стають об’єктом цивільних правовідносин, які не передбачають обов'язкової їх передачі іншій особі, то в такому разі виходить, що обороту благ не відбувається, а тому встановлені обмеження цивільного обороту не поширюються на відповідних осіб. Із цього має випливати, що, наприклад, мисливська зброя, рівно як і радіоактивні речовини, можуть бути предметом застави за умови залишення цих об'єктів у володінні заставодавця. Однак якщо уявити ситуацію, що заставодавець порушив умови основного зобов'язання, що дає можливість заставодержателю набути відповідне майно у власність, то в такому разі перехід права власності без переходу самого блага $є$ неможливим.

3 іншого боку, А.О. Рибалов наводить приклад договору купівлі-продажу частки в праві власності, що слугує на користь позиції, що предметом договору є саме передача прав [6, с. 94]. Цей висновок $є$ небезпідставним, зважаючи на те що предмет права власності на момент продажу частки у праві може перебувати у фактичному володінні, наприклад, орендаря, що виключає «оборот майнового блага», однак передбачає «оборот прав». Убачається, що обмеження цивільного обороту спрямовується в тому числі на недопущення таких випадків, якщо на стороні набувача відсутні необхідні умови, зокрема дозвіл.

У контексті викладеного вище варто погодитися 3 тими вченими, які пов'язують сутність цивільного обороту не лише з переходом права власності й інших прав, а й установленням на їх основі інших правових можливостей 3 іншим, більш обмеженим, змістом [7, с. 13]. Тобто цивільний оборот має стосунок не лише до розпорядження, а й до володіння та користування об'єктом цивільних прав [8, с. 329], адже якщо набуття особою у власність, наприклад, мисливської зброї являтиме собою оборот, а iï одержання в оренду - ні, то в такому разі другий випадок буде використовуватися як легальний шлях обходу встановлених законом обмежень, що суперечить самому сенсу обмеження цивільної оборотоздатності.
Висновки. Узагальнюючи викладене вище, варто констатувати, що категорія «цивільна оборотоздатність» переважно застосовується до об'єктів цивільних прав, зокрема до речей, у силу їх властивостей i потенційної небезпеки для життя і здоров'я фізичних осіб, а також майна фізичних і юридичних осіб. Однак поряд із цим вона застосовується й до суб' єктивних цивільних прав на відповідні майнові блага, оскільки вони нерозривно пов'язані з такими благами.

Проведений аналіз створює підгрунтя для розмежування широкого й вузького розуміння цивільної оборотоздатності суб'єктивних цивільних прав. У широкому розумінні оборотоздатність суб' єктивних цивільних прав позначає їх цивільно-правову життєздатність загалом та об'єктоздатність зокрема. Іншими словами, у такому сенсі оборотоздатність означає здатність окремих правових можливостей, у тому числі права власності, виникати в як суб'єктивних цивільних прав, тобто забезпечених нормами цивільного права правоможностей. У такому розумінні одним із необов'язкових проявів оборотоздатності може бути здатність виступати об'єктом переходу між учасниками цивільних правовідносин.

У свою чергу, у вузькому розумінні оборотоздатність суб'єктивних цивільних прав означає їх здатність вільно відчужуватися або переходити від однієї особи до іншої в порядку правонаступництва чи спадкування або іншим чином. По суті, в такому сенсі йдеться про повну цивільну оборотоздатність суб' єктивних цивільних прав. Тому в контексті розмежування повної оборотоздатності, обмеженої оборотоздатності, а також вилучення об' єкта із цивільного обороту категорія обмеження цивільної оборотоздатності означає можливість суб' єктивного цивільного права виникати лише в певного учасника цивільного обороту або зі спеціального дозволу. У свою чергу, вилучення об' єкта із цивільного обороту означає, що визначене положеннями чинного цивільного законодавства суб'єктивне цивільне право не може виникати на нього, тобто із цивільно-правового погляду є нежиттєздатним.

При цьому проведений аналіз також дає змогу визначити співвідношення між категоріями «відчужуваність» та «оборотоздатність» (у широкому розумінні) суб'єктивних цивільних прав. У цьому сенсі відчужуваність відповідних правових можливостей позначає їх здатність утрачати належність певній особі, зокрема, у зв'язку з переходом 
до іншого учасника цивільних правовідносин. Тобто відчужуваність у такому розумінні характеризує здатність прав утрачати зв'язок із певною особою, належати ій, тоді як оборотоздатність суб'єктивних цивільних прав у широкому розумінні позначає їх здатність виникати й перехо- дити між учасниками цивільних правовідносин у цивільно-правовому порядку, тобто з урахуванням юридичних схематизацій, визначених положеннями чинного цивільного законодавства України та/або актами саморегулювання учасників цивільних правовідносин.

\section{Список літератури:}

1. Цивільний кодекс України : Закон України від 16.01.2003 № 435-IV. Відом. Верхов. Ради України. 2003. № 40-44. Ст. 356 (зі змінами).

2. Про право власності на окремі види майна : Постанова Верховної Ради України від 17.06.1992 № 2471-XII. Відом. Верхов. Ради України. 1992. № 35. Ст. 517.

3. Ухвала Вищого спеціалізованого суду України з розгляду цивільних і кримінальних справ від 25.12.2013, судова справа № 6-46105св13. URL: http://reyestr.court.gov.ua/Review/36369982 (дата звернення: 23.12.2019).

4. Міхно О.І. До питання про визначення майнових прав як об'єктів цивільних правовідносин. Бизнесадминистрирование в условиях турбулентной экономики: материалы Междунар. науч.-практ. интернетконференции (Харьков, 1-28 фев. 2015 г.). Харьков : ХНУГХ имени А.М. Бекетова, 2015. С. 44-47.

5. Сліпченко А.С. Значення дефініції «цивільний оборот» у юриспруденції. Вісник Нац. академ. правових наук Украӥни. 2017. № 1 (88). С. 201-210.

6. Рыбалов А.О. Экономические блага и гражданский оборот. Объекты гражданского оборота : сборник статей / отв. ред. М.О. Рожкова. Москва : Статут, 2007. С. 78-94.

7. Виниченко Ю.В. Гражданский оборот: методологические основания цивилистического исследования. Иркутск : Изд-во БГУЭП, 2014. 166 с.

8. Захаркина А.В. «Гражданский оборот» как фундаментальная цивилистическая категория. Вестн. Пермского ун-та. 2017. Вып. 37. С. 323-333.

\section{Pohrebniak V.Ya. THE ABILITY OF SUBJECTIVE CIVIL RIGHTS TO LEGAL CIVIL CIRCULATION}

The article is devoted to consideration the essence of the ability of subjective civil rights to legal civil circulation as determinant factor for certain forms of their dynamic in sphere of civil relationships.

Searching the ways for theoretical solution of appropriate problem the author conducts deep analyses of current legislative provisions of civil law of Ukraine. It is defined that in correlation with categories of "restriction of ability to legal civil circulation" and "exclusion from legal civil circulation" within text of Art. 178 of Civil Code of Ukraine the category "ability to legal civil circulation" predominantly means the ability of an object to transfer freely according to legal basis among subjects of civil law i.e. full ability to legal civil circulation. Restriction of ability of the objects to legal civil circulation and their exclusion from circulation as a rule related to dangerous features of appropriate objects for participants of legal civil circulation, particularly for their health, lives and/or property.

The author substantiates that both things and subjective civil rights on it are the objects of legal civil circulation. But, also determination of the legal civil circulation only from point of view of transfer of appropriate rights is not proper. The restriction of ability of the object to legal civil circulation directs not only on exclusion the transfer of right of property when special permission is absent but also on exclusion emergence of derivative real rights on it, particularly rent, mortgage etc.

The broad and narrow senses of the ability of subjective civil rights to legal civil circulation are demarcated. It is defined that in a broad sense the ability of appropriate rights to legal civil circulation means their juridical viability generally. That is the ability of appropriate legal possibilities to emerge as subjective rights defined by provisions of current civil legislation and to be an object of circulation. At the same time in a narrow sense ability of subjective civil rights to legal civil circulation means their ability to transfer freely from one person to another under the procedure of succession or inheritance or in any other way (full ability to legal civil circulation).

Key words: legal civil circulation, ability to legal civil circulation, dynamic of subjective civil rights, emergence of civil rights, transfer of civil rights. 